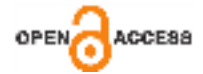

\title{
Analysis of Poverty in Kulon Progo DIY
}

${ }^{1 *}$ Latri Wihastuti, ${ }^{2}$ Rina Oktavia

Email : 1* latri.wihastuti@ugm.ac.id , 2 rina.oktavia@ugm.ac.id

Afiliation: ${ }^{12}$ Universitas Gadjah Mada, Indonesia

* Corresponding Author

\begin{abstract}
Kulon Progo Regency is one of the regencies in the Special Region of Yogyakarta which has a very high percentage of poverty rates. The problem of poverty in Kulon Progo Regency has not yet been resolved. In fact, compared to other regencies/cities in the Special Region of Yogyakarta, the percentage of poor people in Kulon Progo Regency ranks the highest. Various poverty reduction policies have been carried out by the district and provincial governments to reduce poverty rates, but still have not shown significant results. This condition is interesting to analyze considering that poverty policies have not yet had an impact on the condition of Kulon Progo. The purpose of this study was to determine the determinants of poverty in Kulon Progo. This study uses a mixed research approach, namely research that combines quantitative and qualitative research approaches. The results of this study indicate that the inherent characteristics of households in Kulon Progo affect the level of poverty.
\end{abstract}

This is an open access article under the CC-BY-SA license.

\section{Article history}

Received 2021-10-04

Revised 2021-10-27

Accepted 2021-11-02

Keywords

Kulon Progo,

Household

Mix methods,

policy,

poverty,

Kulon Progo,

JEL Classification*:

D12, D13, J22

\section{Introduction}

Kulon Progo Regency is one of the regencies in the Special Region of Yogyakarta Province which has a very high percentage of poverty rates. The problem of poverty in Kulon Progo Regency has not yet been resolved. In fact, compared to other regencies/cities in the Province of the Special Region of Yogyakarta, the percentage of poor people in Kulon Progo Regency in 20162017 ranks the highest, beating Gunung Kidul Regency (see table 1). 
Table 1. Percentage of Poor Regency/City Population

Yogyakarta Special Region 2012 - 2017

\begin{tabular}{lcccccc}
\hline County/City & $\mathbf{2 0 1 2}$ & $\mathbf{2 0 1 3}$ & $\mathbf{2 0 1 4}$ & $\mathbf{2 0 1 5}$ & $\mathbf{2 0 1 6}$ & $\mathbf{2 0 1 7}$ \\
\hline Kulon Progo & 23,32 & 21,39 & 20,64 & 21,40 & 20,30 & 20,03 \\
\hline Bantul & 16,97 & 16,48 & 15,89 & 16,33 & 14,55 & 14,07 \\
\hline Gunung Kidul & 22,72 & 21,70 & 20,83 & 21,73 & 19,34 & 18,65 \\
\hline Sleman & 10,44 & 9,68 & 9,50 & 9,46 & 8,21 & 8,13 \\
\hline Yogyakarta & 9,38 & 8,82 & 8,67 & 8,75 & 7,70 & 7,64 \\
\hline D.I Yogyakarta & $\mathbf{1 5 , 8 8}$ & $\mathbf{1 5 , 0 3}$ & $\mathbf{1 4 , 5 5}$ & $\mathbf{1 4 , 9 1}$ & $\mathbf{1 3 , 3 4}$ & $\mathbf{1 3 , 0 2}$ \\
\hline
\end{tabular}

Source: Strategic Data Yogyakarta 2019

When compared with the poverty rate of the Province of the Special Region of Yogyakarta and Indonesia, the poverty rate of Kulon Progo Regency is far above, even almost double the national poverty rate (see table 2).

Table 2. Poverty Rates (P0) in Kulon Progo Regency, Yogyakarta Special Region Province, and Indonesia in $2012-2017$

\begin{tabular}{lllllll}
\hline Region & $\mathbf{2 0 1 2}$ & $\mathbf{2 0 1 3}$ & $\mathbf{2 0 1 4}$ & $\mathbf{2 0 1 5}$ & $\mathbf{2 0 1 6}$ & $\mathbf{2 0 1 7}$ \\
\hline Kulon Progo & 23,32 & 21,39 & 20,64 & 21,40 & 20,30 & 20,03 \\
\hline Yogyakarta & 15,88 & 15,03 & 14,55 & 14,91 & 13,34 & 13,02 \\
\hline Indonesia & 11,66 & 11,47 & 10,96 & 11,22 & 10,86 & 10,64 \\
\hline
\end{tabular}

Source: BPS 2019

In addition, Kulon Progo Regency's Poverty Depth Index (P1) and Poverty Severity Index (P2) are also very high, exceeding the provincial and national Poverty Depth Index (P1) and Poverty Severity Index (P2) (see table 3).

Various poverty reduction policies have been carried out by district and provincial governments to reduce poverty rates, but have not shown significant results. The government's seriousness in reducing poverty starts from programs that are direct assistance and empowerment. This condition is interesting to analyze considering that poverty policies have not yet had an impact on the condition of Kulon Progo. 
Table 3. Poverty Depth Index (P1) and Poverty Severity Index (P2) Kulon Progo Regency, Yogyakarta Special Region Province, and Indonesia 2013 - 2017

\begin{tabular}{ccccccccccc}
\hline \multirow{2}{*}{\begin{tabular}{c} 
Region \\
\cline { 2 - 11 }
\end{tabular}} & \multicolumn{3}{c}{ Depth Index } & \multicolumn{5}{c}{$\begin{array}{c}\text { Severity Index } \\
\text { Poverty (P2) }\end{array}$} \\
\cline { 2 - 11 } & 2013 & 2014 & 2015 & 2016 & 2017 & 2013 & 2014 & 2015 & 2016 & 2017 \\
\hline Kulon Progo & 2,69 & 3,22 & 4,16 & 3,55 & 2,79 & 0,51 & 0,69 & 1,24 & 1,00 & 0,64 \\
\hline Yogyakarta & 2,13 & 2,19 & 2,93 & 2,30 & 2,19 & 0,46 & 0,48 & 0,83 & 0,59 & 0,55 \\
\hline Indonesia & $\mathbf{1 , 8 9}$ & $\mathbf{1 , 7 5}$ & $\mathbf{1 , 9 7}$ & $\mathbf{1 , 9 4}$ & $\mathbf{1 , 8 3}$ & $\mathbf{0 , 4 8}$ & $\mathbf{0 , 4 4}$ & $\mathbf{0 , 5 3}$ & $\mathbf{0 , 5 3}$ & $\mathbf{0 , 4 8}$ \\
\hline
\end{tabular}

Source :BPS

In general, poverty is the inability of a person to meet basic basic needs in every aspect of life. The Central Statistics Agency (BPS) defines poverty as the inability from an economic point of view to meet basic food and non-food needs as measured from the expenditure side. According to the World Bank (2005) the causes of poverty include: (i) Regional characteristics, including: regional inequality, regional isolation, regional infrastructure conditions, climate, environment, and local government governance; (ii) Community characteristics, including: availability of infrastructure, land distribution, accessibility to public facilities, social structure, and capital structure; (iii) Household characteristics, including: household dependency ratio, gender of the head of the household, labor and household income structure, asset ownership, average level of education and health of household members; and (iv) individual characteristics, including: age, education, workforce, health status, and ethnicity.

Several similar studies have been conducted, including research by Saragih (2015) on poverty alleviation policies in the Special Region of Yogyakarta. According to Saragih (2015), several efforts need to be made to alleviate poverty in the Special Region of Yogyakarta, including creating new jobs, increasing business opportunities for the poor, and increasing the budget for both the state budget and regional budgets. In addition, Zamhari et al (2015) conducted a study on the determinants of poverty in East Java and found that the determinants of poverty that had a significant effect on poverty in East Java were the number of family members, telecommunication facilities and the status of the household area.

Considering the high level of poverty in Kulon Progo Regency, it is necessary to conduct a study related to poverty. The main purpose of this study is to analyze the development of poverty conditions and determine the determinants of poverty in Kulon Progo so that this research provides a new contribution to the previous literature. 


\section{Literature Review}

Several similar studies have been conducted, including research by Saragih (2015) on poverty alleviation policies in the Special Region of Yogyakarta. According to Saragih (2015), several efforts need to be made to alleviate poverty in the Special Region of Yogyakarta, including creating new jobs, increasing business opportunities for the poor, and increasing the budget for both the state budget and regional budgets. In addition, Zamhari et al (2015) conducted a study on the determinants of poverty in East Java and found that the determinants of poverty that had a significant effect on poverty in East Java were the number of family members, telecommunication facilities and the status of the household area. Niswati (2014) conducted a study on the factors that influence poverty in the Special Region of Yogyakarta in 2003-2011 and found that the cause of high poverty in Yogyakarta was the low level of education and health which led to low labor productivity. The wages received by workers are also below the regional minimum wage. Meanwhile, inflation has continued to rise over the past few years. Meanwhile, the variables of education, inflation and the regional minimum wage have no effect on poverty in DIY. The variables of health and labor productivity have a negative effect on poverty in DIY and the regional minimum wage has a positive effect on poverty in DIY. Puspita (2014) conducted a study on the analysis of the determinants of poverty in Central Java Province and found that the number of unemployed, GRDP and total population had a significant effect on poverty. Meanwhile, Djannata $(\mathrm{tt})$ conducted research on the analysis of poverty reduction programs according to SKPD (Regional Work Units) in Semarang City using the AHP (Analytical Hierarchy Process) method. He found that the JAMKESMAS program was the main priority with the highest weight of the ten alternative policies in an effort to reduce poverty in the city of Semarang.

\section{Research Methods}

This study uses a mixed research approach, namely research that combines quantitative and qualitative research approaches. According to Sugiyono (2014), combined research (mix methods) is a research method that combines or combines quantitative methods with qualitative methods to be used together in a research activity, in order to obtain more comprehensive, valid, reliable and objective data.

The type of data used in this research is secondary data. Secondary data that will be used include general description of poverty in Kulon Progo Regency, track record of poverty reduction policies (programs), and data on the economic condition of Kulon Progo Regency. The presentation of existing data in descriptive statistics includes data presentation through tables, pictures, diagrams (bar, circle and scatter) circles, histograms, calculation of the mean, median, 
mode, calculation of the spread of data and through the calculation of the average and standard deviation. This analysis will help summarize the data and describe poverty conditions and existing policies in Kulon Progo Regency.

Based on the objective of the first study, namely to determine the determinants of poverty in the Kulon Progo District Headquarters, a combination of quantitative and qualitative analysis is needed. Regression quantitative analysis is expected to be able to explain the associative relationship through statistical figures between the dependent variable and the independent variable. In this study, a model that refers to the research of Maloma (2019) and Majet \& Malik (2014) will be used with modifications to the dependent variable used. The following is the model used in this study:

$$
\mathrm{LnPOV}_{t}=\beta_{0}+\beta_{1} D D K_{t}+\beta_{2} \operatorname{LnAGE_{t}}+\beta_{3} D E S_{t}+\beta_{4} D G E N_{t}+\beta_{6} L n H H S_{t}+\beta_{7} \operatorname{LnLS} S_{t}+e_{t}
$$

Where LnPOV is the log of household per capita expenditure, LnHHS is the log of the number of household members, DGEN is the dummy gender of the head of the household, and LnLS is the log of the average length of schooling of the household head. Meanwhile, LnES, DDK and Ln Age are logs of the work status of the head of the household, the Village/City dummy and the log of the age of the head of the household. Furthermore, $0, \ldots, 7$ is a regression coefficient.

\section{Result and Discussion}

To find out the factors that influence poverty in Kulon Progo, this study uses micro data sets at the household level. Based on descriptive statistical analysis, the sample used in this study can be seen in table 4.

Table 4. Results of Descriptive Statistics of Variables

\begin{tabular}{lrrrrr}
\hline & N & \multicolumn{1}{c}{ Minimum } & \multicolumn{1}{c}{ Maximum } & \multicolumn{1}{c}{ Mean } & \multicolumn{1}{c}{ Std. Deviation } \\
\hline DDK & 624 & .00 & 1.00 & .3157 & .46517 \\
DGEN & 624 & .00 & 1.00 & .8590 & .34833 \\
AGE & 624 & 22.00 & 80.00 & 53.3542 & 12.47706 \\
DES & 624 & .00 & 1.00 & .2500 & .43336 \\
HHS & 624 & 1.00 & 9.00 & 3.5737 & 1.51218 \\
POV & 624 & $234,173.82$ & $4,961,478.77$ & $937,106.8535$ & $665,252.33492$ \\
LS & 624 & 1.00 & 18.00 & 8.4535 & 3.75464 \\
Valid N & 624 & & & & \\
(listwise) & & & & & \\
\hline
\end{tabular}

Source: data Processing result, 2021 
Table 5 shows that the average value for per capita household expenditure is Rp. 937,106.82, while the highest expenditure is Rp. 4,961,478.77 and the lowest is Rp. 234,173.82. Thus the range between the lowest and highest expenditures is quite wide. More than half of the data show that the highest per capita household expenditure is in the interval 0 to Rp. 1,000,000,- where the head of the household works with non-employee status (see Figure 1). While the highest education of the head of the family is dominated by elementary school graduates. For details on the pattern of data distribution from each independent variable, it can be seen in the following table:

Table 5. Distribution of Expenditures Per Capita

\begin{tabular}{lc}
\hline Range & Frequency \\
\hline $0-1.000 .000$ & 410 \\
$1.000 .001-$ & 177 \\
2.000 .000 & 22 \\
$2.000 .001-3000000$ & 11 \\
$3.000 .001-4000000$ & 4 \\
$4.000 .001-5000000$ & 0 \\
More & \\
\hline
\end{tabular}

Source: Data Processing reults, 2021

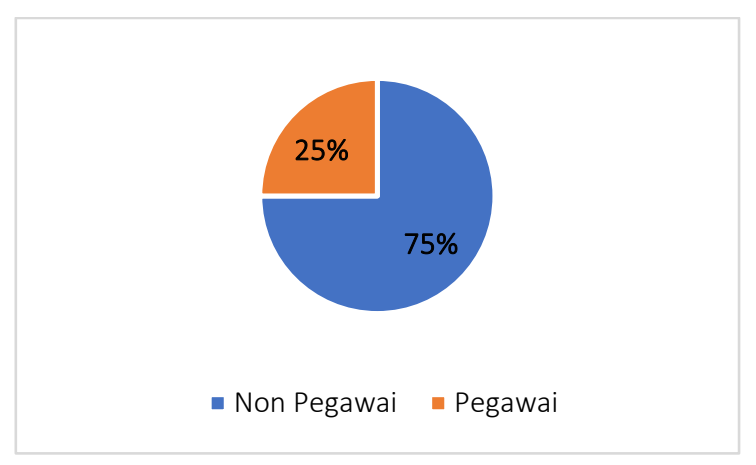

Source: Data Processing result, 2021

Figure 1. Occupational Status of the Head of the Household

Meanwhile, the results of the regression to test the determinants of poverty in Kulon Progo that have passed the classical assumption test can be seen in the table below 6 . The estimation results of the regression coefficients show that the independent variable which is statistically significant affects per capita expenditure (POV) as a representation of the level of income. household poverty is a variable length of schooling (LS) and number of family members (HHS) with 
a negative relationship. This is especially interesting for the length of schooling with a negative effect explaining that people with higher education actually have lower expenditures than other residents. This is interesting because it indicates that productivity is higher not in higher household heads but on the contrary. Another significant variable is DDK which shows that per capita expenditure is higher in rural areas than in cities with a difference of $0.2 \%$.

Table 6. Regression result

\begin{tabular}{lcr}
\hline \multicolumn{1}{c}{ Independent Variable } & coefisient & t - Statistic \\
\hline DDK & $-0.2416^{* * *}$ & -4.7794 \\
\hline LnAGE & 0.0278 & 0.2677 \\
\hline DES & 0.0669 & 1.1652 \\
\hline DGEN & -0.0334 & -0.5051 \\
\hline LnHHS & $-0.3371^{* * *}$ & -7.1318 \\
\hline LnLS & $-0.1198^{* *}$ & -2.5202 \\
\hline C & $14.1709^{* * *}$ & 30.5038 \\
\hline R2 & \multicolumn{2}{c}{0.1206} \\
\hline F-statistic & \multicolumn{2}{c}{$14.0994^{* * *}$} \\
\hline
\end{tabular}

Source: data Processing result, 2021

Meanwhile, the variables of age (AGE), working status (DES), and gender (DGEN) of the head of the family did not have a statistically significant effect on POV. However, the gene coefficient shows that the per capita expenditure of male family heads is lower by $0.03 \%$ than women and the status of family heads who work as laborers/employees/staff has a higher per capita expenditure of $0.06 \%$ than others.

In 2016-2019 there was a decrease in the number of poor people in Kulon Progo Regency, but in terms of the percentage of poor people in Kulon Progo Regency, it still occupies the highest position when compared to other regencies/cities in the Special Region of Yogyakarta. Based on the 2019 Kulon Progo Regency macroeconomic report, several factors that caused the increase in the poverty rate in Kulon Progo Regency were the 2018 increase in the poverty line in Kulon Progo Regency to IDR 323,105. Furthermore, the poverty line increased in 2019 in Kulon Progo Regency to Rp. 333,781, meaning that every resident of Kulon Progo Regency with an expenditure value below Rp. 333,781, for a month was included in the category of poor people. In addition, the existence of Yogyakarta International Airport cannot be enjoyed evenly and as a whole by the 
community, even though at a macro level, Kulon Progo Regency enjoys the inflow of money. Other causes are the consumptive lifestyle of the community, while productivity has not increased, limited skills and education that do not meet the qualifications of the job market. The high poverty line that is not followed by an increase in people's income causes a high number of people who are categorized as poor.

Efforts to reduce the number of regional poverty are carried out through the regional program "Program for Strengthening the local economy through community economic empowerment with the spirit of buying and selling Kulon Progo. Thus, OPD programs lead to the achievement of these targets. The programs that lead to these targets consist of protection and social empowerment, women's empowerment and child protection, food, community and village empowerment, small and medium business cooperatives, investment, marine fisheries, tourism, agriculture, trade, industry, and transmigration.

\section{Conclussion}

The results of this study indicate that the poverty alleviation efforts carried out by the Kulon Progo district government still need to be continued and improved. Although the policies and programs that have been taken have targeted the basic service sector such as education and employment, the results are still not satisfactory. This can be seen from the results of testing with regression where the independent variables at the household level have not given results as expected.

Based on the conclusions above, there are several recommendations that can be taken into consideration for the Kulon Progo Regency government, including the government needs to focus on efforts to provide employment opportunities that can accommodate workers with medium skill and knowledge levels to reduce the rate of regional emigration. The expenditure of poor households which tends to be higher in the village needs to be investigated further regarding the causes so that more targeted policies can be given.

\section{References}

Ringkasan Eksekutif Kondisi Kemiskinan Kabupaten Kulon Progo 2017. (2017). Yogyakarta: Magna Raharja Tama Yogyakarta.

Kabupaten Kulon Progo dalam Angka 2018. (2018). Yogyakarta: Solo Grafika Utama.

Badan Pusat Statistik Kabupaten Kulon Progo. (2017). Data Strategis Kabupaten Kulon Progo 2017. Yogyakarta: Magna Raharja Tama Yogyakarta. 
Kuncoro, M. (2004). Otonomi dan Pembangunan Daerah: Reformasi, Perencanaan, Strategi, dan Peluang. Jakarta: Erlangga.

Niswati, K. (September 2014). Faktor - factor yang Mempengaruhi Kemiskinan di Daerah Istimewa Yogyakarta Tahun 2003 - 2011. EKO-REGIONAL, Vol. 9, No. 2.

Puspita, D. W. (2015). Analisis Determinan Kemiskinan di Provinsi Jawa Tengah. Journal of Economics and Policy 8 (1) , $100-107$.

Saragih, J. P. (Juni 2015). Kebijakan Pengentasan Kemiskinan di Daerah Istimewa Yogyakarta. Jurnal Ekonomi dan Kebijakan Publik, Vol. 6, No. 1.

Sugiyono. (2014). Metode Penelitian Kuantitatif, Kualitatif, dan R \& D. Bandung: Alfabeta.

Zamhari, J., \& dkk. (2015). Analisis Determinan Kemiskinan di Jawa Timur. Wacana, Vol. 18, No. 1. 